\title{
Assessment of water quality around coal-fired thermal power plant, Bathinda (Punjab), India
}

\author{
Savita Verma* \\ Department of Energy and Environmental Sciences Chaudhary Devi Lal University \\ Sirsa-125055 (Haryana ), India \\ Anju \\ Department of Energy and Environmental Sciences Chaudhary Devi Lal University \\ Sirsa-125055 (Haryana), India \\ ${ }^{*}$ Corresponding author. E-mail: vsavita22@gmail.com
}

\begin{abstract}
In the present study, both the underground and surface water samples around Guru Nanak Dev Thermal Power Plant Bathinda, Punjab, having total installed capacity of $440 \mathrm{MW}$, were analyzed for the physico-chemical parameters viz. $\mathrm{pH}$, Electrical Conductivity (EC), Total Dissolved Solid (TDS), Total Hardness (TH), Calcium $\left(\mathrm{Ca}^{2+}\right)$, Magnesium $\left(\mathrm{Mg}^{2+}\right)$, Total Alkalinity (TA), Carbonate $\left(\mathrm{CO}_{3}{ }^{2-}\right)$, Bicarbonate $\left(\mathrm{HCO}_{3}{ }^{-}\right)$, Chloride $\left(\mathrm{Cl}^{-}\right)$, Phosphate $\left(\mathrm{PO}_{4}{ }^{3-}\right)$, Nitrate $\left(\mathrm{NO}_{3}{ }^{-}\right)$, Fluoride $\left(\mathrm{F}^{-}\right)$and heavy metals such as Cadmium $(\mathrm{Cd})$, Copper $(\mathrm{Cu})$, Lead $(\mathrm{Pb})$, Nickel $(\mathrm{Ni})$ and Zinc $(\mathrm{Zn})$. The correlation coefficients $(r)$ among various water quality parameters of studied underground water samples were calculated. The physical and chemical parameters of groundwater are compared with the drinking water quality standards recommended by Bureau of Indian Standards (BIS) (2012) and World Health Organization (WHO) (2017). On the basis of results obtained in the present study, concentration of Chloride $\left(\mathrm{Cl}^{-}\right)$, Magnesium $\left(\mathrm{Mg}^{2+}\right)$, Fluoride $\left(\mathrm{F}^{-}\right)$and Total dissolved solids (TDS) observed in ground water of Bathinda varied from 30 to $284 \mathrm{mg} / \mathrm{l}$, 120 to $280 \mathrm{mg} / \mathrm{l}, 2.66-3.99 \mathrm{mg} / \mathrm{l}$ and $620-1439 \mathrm{mg} / \mathrm{l}$, respectively which are exceeding the acceptable limits prescribed by WHO (2017) as well as BIS (2012). Also, the concentration of heavy metals viz. cadmium $(0.366$ to $0.437 \mathrm{mg} / \mathrm{l})$, and lead $(0.193$ to $0.353 \mathrm{mg} / \mathrm{l})$ have higher levels than prescribed by WHO and BIS for drinking purpose. Thus, groundwater is not suitable for drinking purposes with prior treatment.
\end{abstract}

Keywords: BIS, Drinking Water Quality, Heavy Metals, Thermal Power Plant, WHO

\section{Article Info}

DOI:10.31018/jans.v10i3.1809

Received: June 22, 2018

Revised: July 17, 2018

Accepted: July 30, 2018

\section{How to Cite}

Verma, S. and Anju (2018). Assessment of water quality around coal-fired thermal power plant, Bathinda, Punjab, India. Journal of Applied and Natural Science, 10(3): 915 - 924

\section{INTRODUCTION}

Coal has been used widely as a thermal energy source as well as fuel for thermal power plants producing electricity. In recent decades, an enormous growth in the Indian energy sector has been noticed. In India, the installed capacity of Power Plant Utilities in 1950 was 1713 MW (CEA, 2016), which has increased to about $3,30,861 \mathrm{MW}$ in 2017 (CEA, 2017; as on 31.12. 2017) The electricity generation has also improved from about $5.1 \mathrm{BU}$ in 1950 to $1,107 \mathrm{BU}$ in the year 2015-16. The share of coal in the total installed capacity of all the power stations is an overwhelming $58.3 \%$, followed by Renewable Energy Sources (18.2\%), Hydro (13.6\%), Gas (7.6\%), Nuclear $(2.0 \%)$ and Oil (0.3\%) (CEA, 2017).

Although, coal-fired power plants are the most widely used plants for electricity generation and can bring much economic prosperity, the legacy of mass emissions of solid particles and hazardous gases into the atmosphere, the discharge of chemicals, ash, and contaminated waters is ancillary to these power plants. Environmental effects of solid wastes generated from coal combustion are mainly associated with interactions with surface and ground waters and effects of this waste on biota.

The availability of quality drinking water is one of the most important social and environmental issues at global level. The protection and management of ground water quality is always a matter of concern. Water quality is the physical, chemical, and biological characteristics of water in relation to a set of standards. Water pollution may be defined as alteration of the physical, chemical or biological properties of water or such discharge of any sewage or trade effluent or of any other liquid, gaseous or solid substance into water as may create a nuisance or render such water injurious to public health, or to domestic, commercial, industrial, agricultural or other legitimate uses, or to the life and health of animals or plants or of aquatic organisms (Water (Prevention and Control of Pollution) Act, 
1974).

Groundwater irrigation has been a major component in agricultural development since 1960s. At present groundwater irrigation is the most dominant form of irrigation in India. The largest component of ground water use is the water extracted for irrigation. $89 \%$ of ground water extracted is used in the irrigation sector, making it the highest category user in India (Ministry of Water Resources, 2014).

Water quality is always influenced by both natural (local climate, geology etc.) as well as anthropogenic factors (irrigation practices, pesticide used etc.) (Ramesh and Elango, 2012). Ground water is the major source of drinking water in India. In order to make ground water sustainable, there is a need to understand the aquifer characteristics as well as its geological setting. This understanding not only helps in designing regulated withdrawal of ground water but also for planning suitable mechanism for ground water recharge.

Various manmade and natural activities are polluting the aquatic ecosystem with heavy metals and chemicals. Most of the drinking water schemes in the Punjab depend on the ground water and the canal water (Bhalla et al., 2011). The association of heavy metals with ground water might present hazards to aquatic life and humans (Levy et al., 1992). Nalawade et al. (2012) analyzed underground and surface water samples collected from the surrounding areas of fly ash dumping site of Parli Thermal Power Station (PTPS) of the Maharashtra, India. Metals such as $\mathrm{As}, \mathrm{Hg}, \mathrm{Zn}, \mathrm{Cu}, \mathrm{Cd}$ and $\mathrm{Pb}$ contents were determined in both underground and surface water samples. The heavy metal pollution index (HPI) indicates that leaching metal from fly ash has contaminated the groundwater as well as surface water. Sarode et al. (2010) has found the concentrations of $\mathrm{Cd}$, Fe, $\mathrm{Mn}, \mathrm{Mg}$, and $\mathrm{Zn}$ in groundwater samples in the vicinity of Bhusawal Thermal Power Plant and ash dumping sites were less the permissible range of Indian standards and WHO. The concentrations of $\mathrm{Ni}$ and $\mathrm{Pb}$ were below the Indian standards but slightly larger than WHO permissible range. The concentration of $\mathrm{Cu}$ was slightly higher than Indian Standards but within the WHO permissible limits. Mittal and Arora (2014) observed that contamination due to heavy metals was high in groundwater from Bathinda. Water of almost all study points was hard and contaminated. Overall, groundwater quality was not suitable for drinking purposes.

The study area investigated - Guru Nanak Dev Thermal Power Plant located in Bathinda (Punjab) is a coal fired thermal power plant. The total installed capability of the power station was $440 \mathrm{MW}$ with four units of $110 \mathrm{MW}$ each. The water supply system of the study area i.e. Bathinda is dependent partially on underground water and substantially on surface water. Punjab is one of the most productive agricultural state in India. More than $83 \%$ of the total land in Punjab state is under agriculture as compared to national average of $40.38 \%$ (Tiwana et al., 2007). Highest yield of food grains $(4,144 \mathrm{~kg} / \mathrm{ha})$ in $2014-2015$ were produced by Punjab in the country (Agricultural Statistics at a Glance, 2015). In Punjab the agricultural fields are cultivated with widespread irrigation by using ground water and the canal water from Beas and Sutlej rivers. The contemplated sources of ground water contamination in the study area are in the form of fly ash and bottom ash from thermal power plant in Bathinda. Heavy metals release from fly ash in groundwater depends largely on bonding between the element and fly ash, its chemical form, and physicochemical properties of water (Fulekar and Dave, 1991; Pandey, 2014). Over four decades of its operation Guru Nanak Dev Thermal Power Plant, Bathinda is liable to have contaminated the groundwater with heavy metals and other contaminants. In the present study, an attempt has been made to identify the level of underground and surface water contamination with major ions and five heavy metals in the surrounding region of the Guru Nanak Dev Thermal Power Plant (GNDTPP) situated in Bathinda city.

\section{MATERIALS AND METHODS}

Water sampling: For the purpose of this study, ground (tube well) water samples around thermal power plant ( $n=5$; GW1 to GW5) and surface water samples ( $n=2$; LW1 to LW2) were collected. Samples were collected through the judgmental sampling method. The water samples were collected in scrupulously cleaned, rinsed with double distilled water and dried high-grade polyethylene bottles of one liter capacity.

Methodology: Each water samples were subjected to physico-chemical parameters viz. pH, Electrical conductivity (EC), Total Dissolved Solid (TDS), Total Hardness (TH), Calcium $\left(\mathrm{Ca}^{2+}\right)$, Magnesium $\left(\mathrm{Mg}^{2+}\right)$, Total Alkalinity (TA), Chloride $\left(\mathrm{Cl}^{-}\right)$, Phosphate $\left(\mathrm{PO}_{4}{ }^{3-}\right)$, Nitrate $\left(\mathrm{NO}_{3}^{-}\right)$and Fluoride $\left(\mathrm{F}^{-}\right)$ and heavy metal analysis viz. $\mathrm{Cd}, \mathrm{Cu}, \mathrm{Pb}, \mathrm{Ni}$, and $\mathrm{Zn}$. All the parameters were analyzed following (APHA 2005) standard methods. $\mathrm{pH}$ and EC were determined by using $\mathrm{pH}$ meter (ELICO LI614 pH analyzer) and EC Meter (ELICO CM 183 EC-TDS analyzer), respectively. Total dissolved solids were calculated by formula given by United States Salinity lab staff (1954). Total Hardness (TH), Calcium (Ca) and Magnesium $(\mathrm{Mg})$ were determined by EDTA titrimetric analysis. Total Alkalinity (TA) and Chloride $\left(\mathrm{Cl}^{-}\right)$were determined by neutralization titration and argentometric titration method, respectively. Phosphate $\left(\mathrm{PO}_{4}{ }^{3-}\right)$, Nitrate $\left(\mathrm{NO}_{3}{ }^{-}\right)$ and Fluoride $\left(\mathrm{F}^{-}\right)$were determined spectrophotometrically by ammonium molybdate + stannous chloride, brucine method and SPADANS (4,5- 
Dihydroxy-3-(p-sulfophenylazo)-2,7-naphthalene disulfonic acid, trisodium salt) method, respectively. All the experiments were conducted in triplicate. The statistical analysis of the experimentally generated data was carried out by using SPSS (Statistical Package for Social Sciences).

Reagents and standards: Chemicals used in the present study were of analytical grade and double distilled water was used throughout the study. All the labware in contact with reagents or samples were cleaned by soaking in dilute 4 moles/l of nitric acid $\left(\mathrm{HNO}_{3}\right)$ overnight and rinsed repeatedly with double distilled water. To analyze trace metal concentrations a flame atomic absorption spectrometer (Lab India AA7000) was used. Calibrants were prepared from a $1000 \mathrm{mg} / \mathrm{l}$ spectrosol solution as well as from the standard solutions prepared in laboratory following APHA (2005) standard methods. Standards and blanks were run simultaneously for background correction and to minimize other sources of error.

\section{RESULTS AND DISCUSSION}

Physicochemical characterization of ground water: Groundwater is one of the major sources of water supply in arid and semi-arid regions of India (Moghaddam et al., 2018). Thus, to protect groundwater quality, assessment of groundwater quality is important. In the present study, the 11 physico-chemical parameters and 5 heavy metals ( $\mathrm{Cd}, \mathrm{Cu}, \mathrm{Pb}, \mathrm{Ni}$ and $\mathrm{Zn}$ ) of both the underground (GW1-GW5) and surface water (LW1-LW2) samples collected around Guru Nanak Dev Thermal Power Plant, Bathinda, Punjab are given in (Table 1 ). In the studied site, ground water was free from any type of colour, odour, and turbidity. The underground water's taste was slightly saline at majority of the locations. While performing statistical analysis, only ground water samples were taken together. In the present study an effort has been made to calculate the correlation coefficient $(r)$ among various water quality parameters of studied underground water sample (Table 2). It provides interrelationship between water quality parameters. The physico-chemical parameters and heavy metals of groundwater are compared with the drinking water quality standards recommended by BIS (2012) and WHO (2017) (Table 1).

$\mathrm{pH}: \mathrm{pH}$ is one of the most important parameter in assessing the quality of water. It measures the hydrogen ion concentration in water. In the present study, the $\mathrm{pH}$ of ground water varied from 7.20 to 8.40 with a mean of 7.64 (Table 1; Fig. 1). $\mathrm{pH}$ indicates that all the underground water samples were neutral to alkaline in nature. The permissible limit of $\mathrm{pH}$ for drinking water is 6.5 to 8.5 (BIS, 2012; WHO, 2017). The $\mathrm{pH}$ of all samples was found within the permissible limits prescribed by BIS (2012) and WHO (2017). Namita et al. (2017) have reported 6.5 to $8.5 \mathrm{pH}$ limits for drink- ing water. The correlation matrix shows that $\mathrm{pH}$ was significantly correlated with $\mathrm{TH}(r=0.937, p$ $0.05), \mathrm{Ca}^{2+}(\mathrm{r}=0.924, \mathrm{p} 0.05), \mathrm{Mg}^{2+}(\mathrm{r}=0.886, \mathrm{p}$ $0.05)$ and TA ( $r=0.932$, p 0.05) (Table 2). Significant correlations of $\mathrm{pH}$ with $\mathrm{TH}(\mathrm{r}=0.332), \mathrm{Ca}^{2+}$ $(r=0.360), \mathrm{Mg}^{2+}(r=0.300)$ and TA $(r=0.372)$ were observed by Gupta et al. (1994) in Agra ground water.

Electrical conductivity (EC) and total dissolved solids (TDS): Conductivity is a good indicator to assess groundwater quality and TDS is the concentration of all dissolved minerals in water, which indicates the general nature of salinity of water. Conductivity of water is proportional to its dissolved mineral matter content and varies directly with the temperature changes. EC and TDS of water signifies the amount of total dissolved solids (TDS) or salinity present in it, which in turn shows the inorganic pollution load of water. The EC $(\mathrm{mS} /$ $\mathrm{cm}$ ) of ground water of the study area varied from 0.969 to 2.249 with an average of 1.68 . The concentration of total salt content in irrigation waters, obtained in terms of electrical conductivity (EC), is considered as the important parameter for judging the suitability of irrigation waters.

FAO guidelines classification for EC have been generally used in literature (Al-Bassam and AlRunikhani, 2003; Rasouli et al., 2012). According to FAO guidelines, irrigation water with an EC of $<700 \mu \mathrm{Scm}^{-1}$ causes no risk to crops, while EC of more than $3,000 \mu \mathrm{Scm}^{-1}$ restricts their growth. In general, all irrigation waters having less than 2.25 $\mathrm{mS} / \mathrm{cm}$ conductivity are considered suitable. Ultimate ideal value is less than $0.75 \mathrm{mS} / \mathrm{cm}$ and the waters broadly used have the EC values between 0.75-2.25 mS/cm (Richards, 1954). Salinization $\left(\mathrm{EC}>3000 \mu \mathrm{S} / \mathrm{cm}\right.$ at $25^{\circ} \mathrm{C}$ ) of the groundwater of Bathinda has been reported by Rahi (2011). In the present study TDS ( $\mathrm{mg} / \mathrm{l})$ of ground water of Bathinda varied from 620 to 1439 with an average of 1072. According to BIS (2012) and WHO (2017) the acceptable level of TDS in ground water for domestic purposes is $500 \mathrm{mg} / \mathrm{l}$ and the extreme permissible limit is $2000 \mathrm{mg} / \mathrm{l}$. On the basis of the classification done by Rabinove et al. (1958) the ground water with TDS $1000-3000$ ppm is considered slightly saline. So, the ground water of the study area falls in the class of non saline to slightly saline. The presence of high levels of TDS (above $1200 \mathrm{mg} / \mathrm{L}$ ) in drinking water is generally taste wise unacceptable for human beings (Bhalla et. al., 2011). The presence of high levels of TDS may also be objectionable, owing to extreme scaling in household appliances, heaters, boilers, and water pipes. In case of non-availability of any other water source, underground water of the study area may be used for drinking and irrigation purposes from salinity point of view.

Total hardness (TH), calcium $\left(\mathrm{Ca}^{2+}\right)$ and magnesium $\left(\mathrm{Mg}^{2+}\right)$ : Total Hardness (TH) is mainly be- 


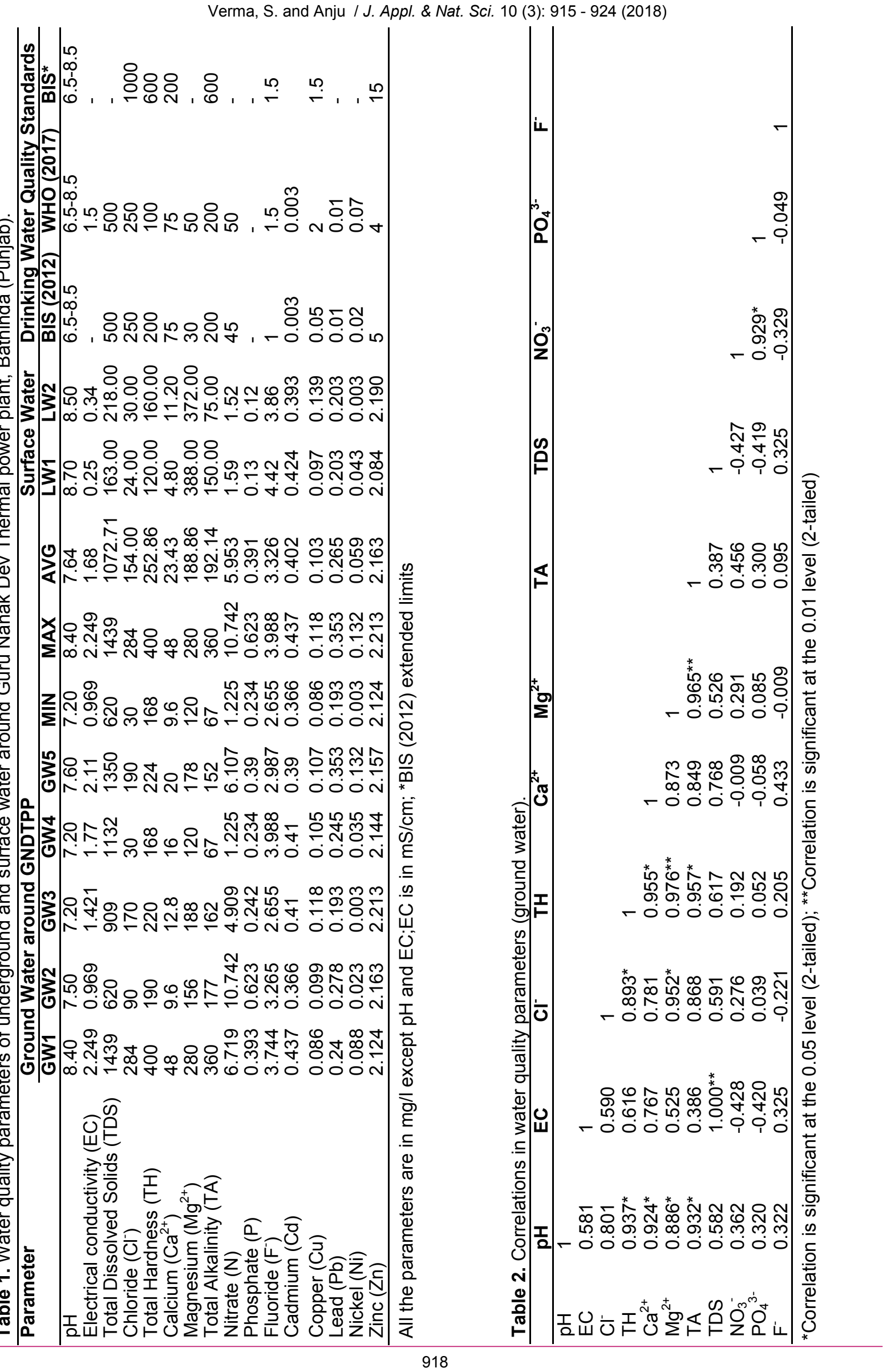


Verma, S. and Anju / J. Appl. \& Nat. Sci. 10 (3): 915 - 924 (2018)
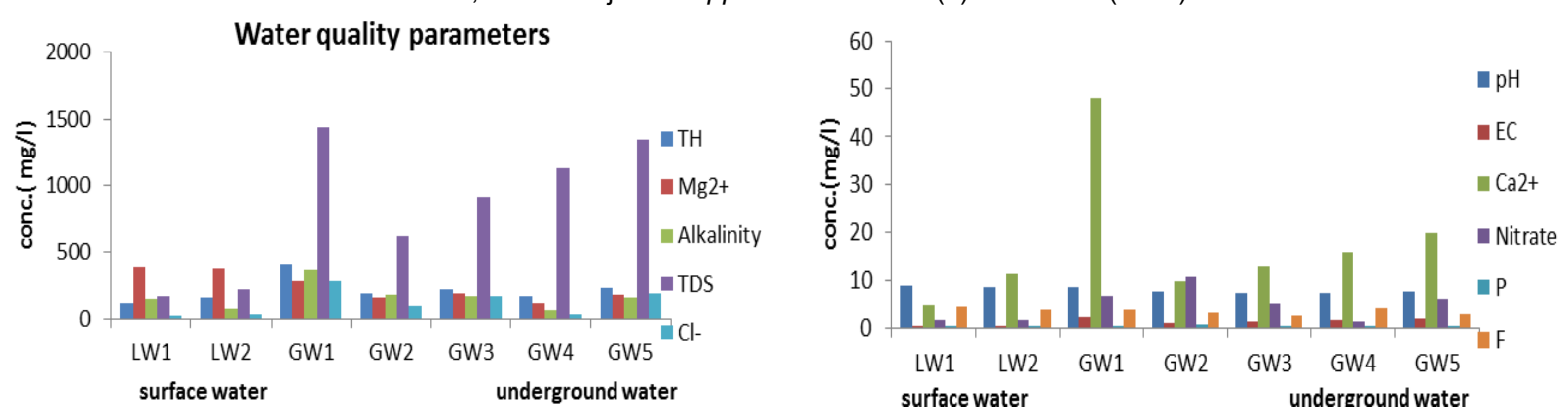

Fig. 1. Water quality parameters (All the parameters are in $\mathrm{mg} / \mathrm{l}$ except $\mathrm{pH}$ and EC. EC is in $\mathrm{mS} / \mathrm{cm}$ ).

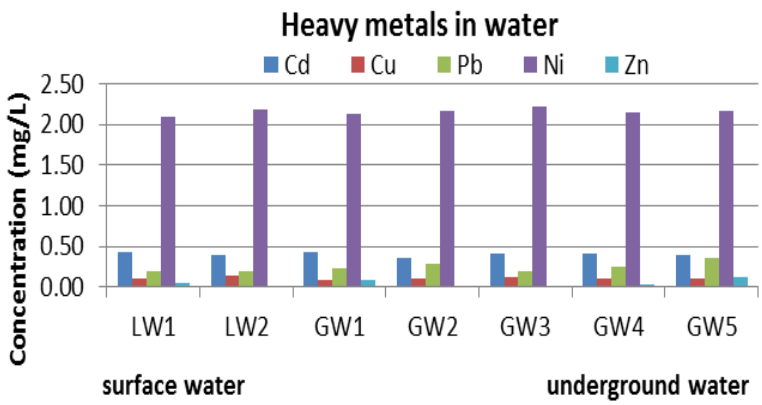

Fig. 2. Heavy metals in surface and underground water.

cause of carbonates, sulphates and chlorides of calcium and magnesium present in ground water. It is generally expressed as milligrams of calcium carbonate per litre $\left(\mathrm{mg} \mathrm{CaCO}_{3} / \mathrm{l}\right)$. Calcium and magnesium are dissolved from most soils and rocks. The hardness of natural waters depends primarily on the presence of dissolved calcium and magnesium salts. A limit of $300 \mathrm{mg} / \mathrm{l}$ has been recommended for potable water and the maximum permissible limit of hardness is $600 \mathrm{mg} /$ $\mathrm{I}$ in case of non-availability of any other source (BIS, 2012). Total Hardness (mg/l) in groundwater of the study area varied from 168 to 400 with an average of 252.86 . The degree of hardness of potable water has been classified as : Soft- 0-60 mg/l, Medium- 60-120 mg/l, Hard- 120-180 mg/l, terribly hard- > $180 \mathrm{mg} / \mathrm{l}$ (in terms of equivalent $\mathrm{CaCO}_{3}$ concentration) ( Dohare et al., 2014). On the basis of the classification done by Durfor and Becker (1964), the water with hardness $>180 \mathrm{ppm}$ is considered very hard. So, the ground water of the study area is very hard. Hardness in all the water samples is above the WHO (2017) desirable limit of $100 \mathrm{mg} / \mathrm{l}$.

Calcium is the fifth most abundant element found on the earth crust. Calcium and magnesium are important parameter for total hardness. It is most common in natural as well as ground water. The presence of calcium in drinking water may be of natural geological, industrial, mining or agricultural origin. The desirable limit of calcium for drinking water is $75 \mathrm{mg} / \mathrm{l}$ (WHO, 2017; BIS, 2012) and maximum permissible limit of calcium is $200 \mathrm{mg} / \mathrm{l}$ in case of non-availability of any other source (BIS, 2012). Calcium content in the present study trembled from 9.6 to $48 \mathrm{mg} / \mathrm{l}$ with a mean of 23.43 $\mathrm{mg} / \mathrm{l}$. These results show that the calcium content in ground water is within range recommended by WHO (2017) as well as BIS (2012). Calcium is important for human beings in the formation of bones and also plays an important role in nervous system.

A significant number of minerals contain magnesium; it is washed from rocks and subsequently ends up in water. Magnesium is present in the environment also due to fertilizer application and from cattle feed (Deshapnde et al., 2012). Its high concentration gives unpleasant taste to the water. In human body magnesium tolerance power is less than that of Calcium. The acceptable limit and maximum permissible limit for magnesium (mg/l) in drinking water are 30 and 100, respectively (BIS, 2012). As per WHO standards, the permissible limit of $\mathrm{Mg}$ is $50 \mathrm{mg} / \mathrm{l}$ (WHO, 2017). Concentration of $\mathrm{Mg}$ observed in ground water trembled from 120 to $280 \mathrm{mg} / \mathrm{l}$ with a mean of $188 \mathrm{mg} / \mathrm{l}$. The results show that the level of $\mathrm{Mg}$ in ground water are above permissible limit prescribed by $\mathrm{WHO}$ (2017) as well as BIS (2012). In the present study, magnesium was found to be the parameter due to which most of the groundwater samples are contaminated and non potable. Mittal and Arora (2014) observed that magnesium is the second major element of hardness and it usually comprises $15-20 \%$ of the total hardness expressed as $\mathrm{CaCO}_{3}$. A higher concentration of calcium and magnesium indicates hardness in groundwater (Gulgundi and Shetty, 2018).

Total hardness is significantly and positively correlated with calcium $(r=0.955, p=0.05)$, magnesium $(r=0.976, p=0.01)$ and total alkalinity $(r=0.957$, $\mathrm{p}=0.05)$. Significant correlations between $\mathrm{TH}-\mathrm{Ca}$ $(0.530)$ and $\mathrm{TH}-\mathrm{Mg}(0.645)$ have also been reported by Shalu et al. (2015) in underground water of Bhiwani, Haryana, India. Meenakshi et al. (2004) have also observed significant correlations between TH-Ca (0.844) and TH-Mg (0.981). Significant and positive correlations between total hardness and magnesium have been observed frequently in literature. Kesavan and Parmeswari (2005; r=0.900) in groundwater from Kancheepuram, Jeyaraj et al. (2002; $r=0.951)$ in ground water from Thiruchirappalli and Bhatia et 
al. (2008; $r=1.000)$ in groundwater from Dabwali have also observed significant correlations between $\mathrm{TH}$ and Mg. Significant correlation coefficients between $\mathrm{Ca}-\mathrm{Mg}$ have been reported by Rao et al. (2006; $r=0.77)$ in groundwater from Anantapur (A.P.) and Bhatia et al. (2008; $r=0.516$ ) in ground water from Dabwali (Haryana). Gupta et al. (1994) analyzed groundwater from Agra (India) and observed significant correlation coefficients between $\mathrm{Mg}-\mathrm{Ca}$ (0.529), ${\mathrm{Mg}-\mathrm{Cl}^{-}}^{-}(0.729) \mathrm{Mg}-\mathrm{TH}$ (0.989), Ca-TH (0.649), and $\mathrm{TH}_{-} \mathrm{Cl}^{-}$(0.736). Sulochna et al. (1998) also observed a strong correlation between $\mathrm{TH}-\mathrm{Mg}(0.94)$ and $\mathrm{Ca}-\mathrm{TH}(0.96)$ in groundwater of Tamil Nadu, India.

Total alkalinity (TA), carbonate $\left(\mathrm{CO}_{3}{ }^{2-}\right)$, and bicarbonate $\left(\mathrm{HCO}_{3}{ }^{-}\right)$: Total Alkalinity (TA) is a measure of ability of water to neutralize acids. Nearly all the natural waters have substantial amounts of dissolved carbon dioxide, which is the main source of alkalinity in water (Ramesh and Elango, 2012). The alkalinity in the water is commonly imparted by the salts of carbonates, bicarbonate, hydroxide, silicates, etc. together with the hydroxyl ions in free state, which may result from dissolution of mineral substances in the atmosphere and soil (Mittal and Verma, 1997).

In the present study alkalinity present in the groundwater is only due to bicarbonate contents, as carbonate alkalinity was absent in the underground water samples. Hydroxide, carbonate and bicarbonate contents are the main contributor of the alkalinity in water (Bansal and Dwivedi, 2018). Behailu et al. (2017) also reported alkalinity in terms of $\mathrm{HCO}_{3}{ }^{-}$in groundwater of Ethiopia. Alkalinity $(\mathrm{mg} / \mathrm{l})$ of the groundwater in present study ranged from 67 to 360 with mean of 192. All the samples of groundwater have TA within the desirable limits $(200 \mathrm{mg} / \mathrm{l})$ recommended for potable water by WHO (2017) and BIS (2012) expect for one sample (GW 1) with the TA of $360 \mathrm{mg} / \mathrm{l}$, which is also within BIS (2012) maximum permissible limit of $600 \mathrm{mg} / \mathrm{l}$ in case of non-availability of any other source. The correlation matrix shows significant and positive correlation between TA- $\mathrm{Mg}^{2+}$ $(r=0.965, p=0.01)$. A strong correlation between TA-Mg (0.421) has also been reported by Meenakshi et al. (2004) in groundwater of Haryana, India.

Chloride $\left(\mathrm{Cl}^{-}\right)$: Chloride occurs in all types of natural waters and its presence can be attributed due to dissolution of salts. Chloride originates generally from sodium chloride, which inturn is dissolved in water from industrial and domestic waste discharges, infiltration of seawater, and from rocks and soil. Chloride in excess of 100 ppm imparts a salty taste. According to BIS (2012) and WHO (2017) the acceptable limit of chloride in potable water is $250 \mathrm{mg} / \mathrm{l}$, which may be further relaxed up to $1000 \mathrm{mg} / \mathrm{l}$ under Indian conditions (BIS, 2012). Beyond $250 \mathrm{mg} / \mathrm{l}$, taste, corrosion, and palatability of water are affected. The chloride content will automatically increases by increasing mineral content in water. As per IS: 10500-2012 acceptable limit of chloride is $250 \mathrm{mg} / \mathrm{l}$ and permissible limit is $1000 \mathrm{mg} / \mathrm{l}$ (Bansal and Dwivedi, 2018). In the present study, ground water chloride content $(\mathrm{mg} / \mathrm{l})$ ranged from 30 to 284 with a mean of 154. All the samples of groundwater have chloride concentration within the acceptable limit expect one sample (GW 1) with chloride concentration of $284 \mathrm{mg} / \mathrm{l}$. So, the ground water of the study area is fit for drinking purpose from chloride point of view.

Significant and positive correlation between $\mathrm{Cl}^{-}$$\mathrm{Mg}^{2+} \quad(r=0.952, \quad p=0.05)$ and $\mathrm{Cl}^{-}-\mathrm{TH} \quad(r=0.893$, $p=0.05$ ) were found. Hence, the presence of chloride in water is strongly influenced by total hardness. Significant correlations between $\mathrm{Cl}^{-}-\mathrm{TH}$ (0.618) and $\mathrm{Cl}^{-}-\mathrm{Mg}(0.545)$ have also been reported by Shalu et al. (2015). Gupta et al. (1994) have also observed strong correlation between $\mathrm{Cl}^{-}-\mathrm{TH}$ (0.736) and $\mathrm{Cl}^{-}-\mathrm{Mg}$ (0.729) in groundwater from Agra (India). Furthermore, significant correlation between $\mathrm{TH}_{-} \mathrm{Cl}^{-}$in groundwater of Tamil Nadu (India) (Sulochna et al., 1998; $r=0.96$ ) and Dabwali (Bhatia et al. 2008; $r=0.686$ ) have also been observed.

Nitrate $\left(\mathrm{NO}_{3}{ }^{-}\right)$: Nitrate $\left(\mathrm{NO}_{3}{ }^{-}\right)$is present naturally in the environment and it is also considered as an important plant nutrient. Nitrate is the highest oxidizable form of nitrogen and is toxic when present in excessive amounts in drinking water (Behailu et al., 2017). Nitrification may occur when excess of free ammonia enters in the distribution system which can also increase of nitrate and nitrite in drinking-water. Nitrate showed toxic effect when it is reduced to Nitrite. Sources of nitrate $\left(\mathrm{NO}_{3}{ }^{-}\right)$in water are nitrate fertilizers, decaying organic matter, sewage, legume plants, and nitrates in soil. Excess nitrate can lead to growth of algae and other organisms that produce undesirable tastes and odors in water system. The maximum permissible limit of nitrate in water is $45 \mathrm{mg} / \mathrm{l}$ (BIS, 2012). In the present study, the nitrate concentration of ground water varied from $1.225-10.742 \mathrm{mg} / \mathrm{l}$ with a mean $5.953 \mathrm{mg} / \mathrm{l}$. The correlation matrix shows significant and positive correlation between $\mathrm{NO}_{3}{ }^{-}$$\mathrm{PO}_{4}{ }^{3-}(r=0.929, p=0.05)$.

Phosphate $\left(\mathrm{PO}_{4}{ }^{3-}\right)$ : Phosphate is an important component from agricultural point of view. In acidic soils phosphate gets adsorbed as iron phosphate or aluminum or as calcium phosphate in neutral or alkaline soils. Thus, the phosphate concentration in ground water is generally low, but different chemical processes in soil strata may cause the mobility of phosphate in sub-soil as well as in ground water. Also, phosphorous is considered as an essential plant nutrient and is widely used as fertilizer. Phosphorus is present as phosphate in natural water as a growth limiting nutrient, 
so that phosphate is essential for the growth of organisms. Though there is no clear permissible limit set for the phosphate ion concentration by $\mathrm{WHO}$ and BIS, some research articles and guidelines suggest that concentration of $0.01 \mathrm{mg} / \mathrm{l}$ of phosphate is acceptable while $0.02 \mathrm{mg} / \mathrm{l}$ is excessive (Behailu et al., 2017). The permissible limit of phosphate in drinking water is $0.1 \mathrm{ppm}$ (USEPA, 2005). In the present study, the phosphate concentration of ground water varied from 0.234 $0.623 \mathrm{mg} / \mathrm{l}$ with a mean of $0.391 \mathrm{mg} / \mathrm{l}$.

Fluoride $\left(\mathbf{F}^{-}\right)$: Generally, fluorine is a common element that is widely distributed in earth's crust. Usually all vegetation contains some fluoride content, which is absorbed from soil and water. Fluorides are present in many waters in trace amounts, with higher concentrations frequently associated with ground waters. Fluoride $\left(\mathrm{F}^{-}\right)$is considered as a necessary element for maintaining normal development of teeth and bones, but higher concentration causes fluorosis problems. In the present study, the fluoride concentration $(\mathrm{mg} / \mathrm{l})$ of ground water varied from 2.66-3.99 with a mean of 3.32. Gulgundi and Shetty (2018) have also found higher concentration of fluoride in the groundwater of urban Bengaluru. When drinking water exceeds the guideline value of $1.5 \mathrm{mg} / \mathrm{l}$ (BIS, 2012), there is an increasing risk of dental and skeletal fluorosis, which makes this element of great health concern in many regions (Mohapatra et al., 2009; Berger et al., 2012). Fluoride content of all the ground water samples was higher than the BIS (2012) and WHO (2017) permissible limits. Fluoride was found to have no significant correlation with any other studied parameters. Shalu et al. (2015), Meenakshi et al. (2004) and Bhatia et al. (2008) also did not find fluoride to be significantly correlated with any other water quality parameters.

Heavy metal concentrations in ground water: Once metals are introduced and contaminate the environment, they remain there. Metals do not degrade like carbon-based (organic) molecules. The accumulation of heavy metals in water and soil is of increasing concern due to the safety issues of drinking water and food. Heavy metal pollution in ground water affects the agricultural soil's properties and thus influences on production of crops have been reported in literature. Heavy metals release from fly ash in groundwater depends largely on bonding between the element and fly ash, its chemical form, and physicochemical properties of water (Fulekar and Dave, 1991; Pandey, 2014).

Cadmium: Cadmium is considered as a potential environmental contaminant. Concentration of $\mathrm{Cd}$ $(\mathrm{mg} / \mathrm{l})$ in groundwater varied 0.366 to 0.437 with a mean of 0.402 (Table 1; Fig. 2). As per the WHO and BIS standards permissible limit for cadmium is $0.003 \mathrm{mg} / \mathrm{l}$ with no extendable limits in drinking water. The cadmium concentration of the ground water samples was detected higher than the desired limit. Similarly, Mittal and Arora (2014) have reported $\mathrm{Cd}$ level $0-0.001 \mathrm{mg} / \mathrm{l}$ in underground water of Bathinda. Edokpayi et al. (2018) has found the concentration of $\mathrm{Cd}$ was below the standard limits set by WHO $(0.003 \mathrm{mg} / \mathrm{l})$, for domestic water use in groundwater of South Africa.

Copper: Copper is considered as essential trace element for dietary requirement, however; astringent tastes in water can be caused by levels above $1 \mathrm{mg} / \mathrm{l} \mathrm{Cu}$ (Behailu et al., 2017). Cu (mg/l) in groundwater ranged from 0.086 to 0.118 with a mean of 0.103 . As per the WHO and BIS standards permissible limit for copper is $0.05 \mathrm{mg} / \mathrm{l}$ and extendable up to $1.5 \mathrm{mg} / \mathrm{l}$ in drinking water. All the ground water samples have the copper concentration comfortably within desired limit. Copper also imparts a colour and an undesirable bitter taste to water at levels above $5 \mathrm{mg} / \mathrm{l}$. Copper should be acceptable at the health-based guideline value of $2 \mathrm{mg} / \mathrm{l}$. Sarode et al. (2010) observed Cu concentration 0.057 in ground water in the vicinity of Bhusawal Thermal Power Plant. Mittal and Arora (2014) reported Cu level 0.002-0.108 $\mathrm{mg} / \mathrm{l}$ in the underground water of Bathinda.

Lead: The almost universal use of lead pipes in old water distribution systems and plumbing fittings (Behailu et al., 2017). The permissible limit of lead in drinking water as prescribed by WHO and BIS is $0.01 \mathrm{mg} / \mathrm{l}$, although in present study concentration of lead ranged from 0.193 to 0.353 $\mathrm{mg} / \mathrm{l}$ with an average of $0.265 \mathrm{mg} / \mathrm{l}$. Lead concentration in all groundwater samples around TPP is observed exceeding the prescribed limit of $\mathrm{WHO} /$ BIS. Mittal and Arora (2014) reported $\mathrm{Pb}$ level $0.013-0.023 \mathrm{mg} / \mathrm{l}$ in the underground water of Bathinda. Verma et al. (2016) observed 0.463 ppm $\mathrm{Pb}$ level in underground water around coalfired thermal power plant, Parichha, Jhansi, India. Jaredaa et al. (2018) has also found higher $\mathrm{Pb}^{2+}$ concentrations than WHO permissible limit in groundwater of Bailadila iron ore mine area, Chhattisgarh.

Nickel: As per the WHO and BIS standard permissible limits of the nickel in drinking water are $0.07 \mathrm{mg} / \mathrm{l}$ and $0.02 \mathrm{mg} / \mathrm{l}$, respectively. Concentration of $\mathrm{Ni}(\mathrm{mg} / \mathrm{l})$ in groundwater is observed to vary from 0.003-0.132 with an average of 0.059 and it was above the prescribed permissible limits of BIS and within permissible limits of $\mathrm{WHO}$. Sarode et al. (2010) observed Ni concentration 0.040 in water around Bhusawal TPP, Maharashtra. Verma et al. (2016) observed 0.059 ppm Ni level in underground water around coal-fired thermal power plant, Jhansi, India.

Zinc: Mostly zinc is introduced into water by anthropogenic activities such as burning of waste materials, byproducts of coal -fired power station or steel production or from, fertilizer that may 
leach into groundwater. Drinking water contains $\mathrm{Zn}$ in very small quantities which may reduce the possibility of its deficiency in the diet (Behailu et al., 2017).

WHO and BIS standard permissible limit for zinc is $5.0 \mathrm{mg} / \mathrm{l}$ in potable drinking water. Concentration of $\mathrm{Zn}(\mathrm{mg} / \mathrm{l})$ in groundwater ranged from 2.124 to 2.213 with an average of 2.163 . The concentration of zinc in all the water samples collected is lower than the maximum permissible limit. Mittal and Arora (2014) reported Zn level 0.061$1.98 \mathrm{mg} / \mathrm{l}$ in the underground water of Bathinda. Sarode et al. (2010) observed $\mathrm{Zn}$ concentration 0.075 ppm in groundwater around Bhusawal Thermal Power Plant, Maharashtra.

Surface water quality: Only two samples of surface water were collected from the lake in the vicinity of thermal power plant, Bathinda. Values of the all the parameters analyzed are shown in Table 1. All the parameters except magnesium are within acceptable limits of WHO (2017) and BIS (2012). Magnesium content in surface water samples are above WHO (2017) and BIS (2012) limits. The concentration of $\mathrm{Cd}$ and $\mathrm{Pb}$ are also exceeding the WHO (2017) and BIS (2012) permissible limits.

\section{Conclusion}

From the results obtained from present study, it is concluded that some water quality parameters like $\mathrm{Cl}^{-}, \mathrm{Mg}^{2+}, \mathrm{F}^{-}$and TDS exceeded the acceptable limits prescribed by WHO (2017) as well as BIS (2012) for drinking purpose. According to the calculated correlation coefficients, the highest correlation Coefficient belonged to EC-TDS (1), while $\mathrm{Mg}^{2+}-\mathrm{TH}(0.976)$ and $\mathrm{Mg}^{2+}-\mathrm{TA}(0.965)$ showed strong correlations. However, $\mathrm{PO}_{4}{ }^{3-}$ with $\mathrm{NO}_{3}^{-}, \mathrm{TH}$ and $\mathrm{Mg}^{2+}$ with $\mathrm{Cl}^{-}$and $\mathrm{TA}, \mathrm{Mg}^{2+}, \mathrm{TH}, \mathrm{Ca}^{2+}$ exhibited good positive correlations with $\mathrm{pH}$. The concentrations of $\mathrm{Cd}(0.402 \mathrm{mg} / \mathrm{l})$ and $\mathrm{Pb}(0.265 \mathrm{mg} / \mathrm{l})$ are higher than prescribed limits by WHO and BIS for drinking water. However, $\mathrm{Cu}, \mathrm{Ni}$ and $\mathrm{Zn}$ were within permissible limits of WHO standards. The reason behind the presence of other form of impurities and heavy metals in the ground water could be the leaching of heavy metals from fly ash and bottom ash arising from the thermal power plant into the environment and hence into the groundwater. The study reveals that groundwater is contaminated due to heavy metals. Therefore, groundwater quality is not suitable for drinking purposes and the pretreatment required before consumption. The groundwater may be used for the irrigation purposes but before that proper study should be conducted to ensure that the groundwater will not harm the soil fertility as well as the crop production. Prevention is the best method to protect the environment from contamination by heavy metals. Hence, it is necessary to minimize or reduce the further deterioration of ground water quality in the present study area. The quality of potable water ought to be checked at regular interval.

\section{REFERENCES}

1. Agricultural Statistics at a Glance (2015). Ministry of Agriculture; PRS. Government of India Ministry of Agriculture \& Farmers Welfare Department of Agriculture, Cooperation \& Farmers Welfare Directorate of Economics and Statistics.

2. Al-Bassam, A.M. and Al- Rumikhani, Y.A., (2003). Integrated hydrochemical method of water quality assessment for irrigation in arid areas. Application to the jilhaquifer, Saudi Arabia. J. African Earth Sci. 36: 345-356.

3. American Public Health Association Inc. (APHA) (2005). Standard Methods for the Examination of Water and Wastewater, 21st ed. New York, USA.

4. American Public Health Association Inc. APHA (2012). Standard Methods for the examination of Water, 22nd Edition, New York, USA.

5. Asghari, F.B., Mohammadi, A., Dehghani, M.H., Yousefi, M. (2018). Data on assessment of ground water quality with application of ArcGIS in Zanjan, Iran. Data in Brief. 18:375-379. https:// doi.org/10.1016/j.dib.2018.03.059.

6. Bansal, J., and Dwivedi, A. K. (2018). Assessment of ground water quality by using Water quality index and physico chemical parameters: review Paper. Int. $J$ of engg, sci. \& res. Tech. 7(2): 170-174.

7. Behailu, T.W., Badessa, T.S., Tewodros, B.A. (2017). Analysis of Physical and Chemical Parameters in Ground Water Used for Drinking around Konso Area, Southwestern Ethiopia. J Anal Bioanal Tech. 8: 379. doi: 10.4172/2155- 9872.1000379.

8. Berger, T., Peltol, P., Drake, H., and Astrom, M. (2012). Impact of a Fluorine-Rich Granite Intrusion on Levels and Distribution of Fluoride in a Small Boreal Catchment. Aqua. Geochem. 18:77-94. DOI 10.1007/s10498- 011-9151-2, 2012.

9. Bhalla, A., Singh, G., Kumar, S., Shahi, J.S. and Mehta, D. (2011). Elemental analysis of ground water from different regions of Punjab state (India) using EDXRF technique and the sources of water contamination. In Int Conf Environ Comput Sci. 19:156-164.

10.Bhatia, D., Parkeek, P., Malik, A., Singh, B., Kumar, R., and Bishnoi, K. (2008). Assessment of Ground Water Quality of Parameters and Correlation Analysis of Tehsil Mandi Dabwali, Sirsa, Haryana, India. Pol. Res. 27: 579-586.

11.BIS, (2012). Indian Standard Drinking Water Specification (Second Revision). Bur. Indian Stand. IS 10500, 1-11.

12.Central Electricity Authority, March, 2017. Review of Experience in Strengthening of O\&M Practices in Thermal Power Stations in India. Ministry of Power, Government of India website, /http://www.cea.nic.in.

13.Central electricity authority, October, 2016, Report on fly ash generation at coal/lignite based thermal power stations and its utilization in the country for the year 2015-16.

14.Deshpande, S.M. and Aher, K.R. (2012). Evaluation of Groundwater Quality and its Suitability for Drinking and Agriculture use in Parts of Vaijapur, District Aurangabad, MS, India. J. Chem. Sci. 2(1):25-31.

15.Deshpande, S.M., Aher, K.R., and Gaikwad, G.D. (2012). Assessment of Groundwater Quality and its 
Suitability for Drinking Uses in Warora tehsil, District Chandrapur, India. Int. J. Rec.Tren. Sci. Technol. 4 (3): 2249-8109. ISSN 2277-2812 E-ISSN.

16.Dohare, D., Deshpande, S. and Kotiya, A. (2014). Analysis of Ground Water Quality Parameters: A Review. Res. J. of Engg. Sci. 3(5):26-31. ISSN: 2278 $-9472$.

17.Durfor, C.N. and Becker, E. (1964). Public water supplied of the 100 largest cities in the U.S., US Geological Survey. Water Supply Paper. 1812: 364.

18.Edokpayi, J.N., Enitan, A.M., Mutileni, N. and Odiyo, J.O. (2018). Evaluation of water quality and human risk assessment due to heavy metals in groundwater around Muledane area of Vhembe District, Limpopo Province, South Africa. Chem. Central J. 12:2. https://doi.org/10.1186/s13065-017-0369-y.

19.Fulekar, M. H., and Dave, J. M. (1991). Release and behavior of $\mathrm{Cr}, \mathrm{Mn}, \mathrm{Ni}$ and $\mathrm{Pb}$ in a fly-ash/soil/water environment: Column experiment. Int. J. Environ. Stud. 38: 281-296. http:// dx.doi.org/10.1080/00207239108710673.

20.Gulgundi, M.S., and Shetty, A. (2018). Groundwater quality assessment of urban Bengaluru using multivariate statistical techniques. Applied Water Sci. 8:43. https://doi.org/10.1007/s13201-018-0684-z.

21.Gupta, R.K., Singh, N.T. and Sethi, M. (1994). Ground water quality for irrigation in India. Indian J. Environ HIth. 36(1): 43-46.

22.Jaredaa, G., Mahapatraa, S.P., and Dhekneb, P.Y. (2018). Water quality index, heavy metal pollution index and seasonal variation correlation of groundwater of Bailadila iron ore mine area and its peripherals:Dantewada district, Chhattisgarh, India. Desalination and Water Treatment. 101: 7-16. doi: 10.5004/ dwt.2018.21632.

23.Jeyaraj, T., Padmavathy, S., and Jebakumari, S.S.H. (2002). Correlation among water quality parameters for groundwater samples of Bharathi Nagar of Thiruchirappalli City. Indian J. Environ. Prot. 22:755-759.

24.Kesavan, K.G., and Parameswari, R. (2005). Evaluation of groundwater quality in Kancheepuram. Indian J. Environ. Prot. 25:235-239.

25.Levy, D.B., Barbarick, K.A., Siemer, E.G., and Sommers, L.E. (1992). Distribution and partitioning of trace metals in contaminated soils near Leadville, Colorado. J. Environ. Qual. 21:185-195.

26.Meenakshi, Garg, V.K., Kavita, Renuka and Malik, A. (2004). Groundwater quality in some villages of Haryana, India: Focus on fluoride and fluorosis. J. Hazard. Mater. 106: 85-97.

27.Ministry of Water Resources, Annual Report 201314. River Development and Ganga Rejuvenation, http://wrmin.nic.in/writereaddata/AR_2013-14.pdf.

28.Mittal, S., and Arora, S.K. (2014). A Study of Evaluation of Groundwater Quality of Bathinda Region of Punjab. Int. J. Engg. and Innovat. Tech. 4 (1): 149154.

29.Mittal, S.K., and Verma, N. (1997). Critical analysis of ground water quality parameters. Indian J. Environ. Prot. 17:426-429.

30.Moghaddama, A., Moteallemib, A., Joulaeic, F. and Peirovi, R. (2018). A spatial variation study of groundwater quality parameters in the Gonabad Plain using deterministic and geostatistical models. J. of Desalination and Wat. Treat.103:261-269. doi:10.5004/dwt.2018.21614.

31.Mohapatra, M.S., Mishra, B.K., Giles, D.E., and
Singh, P. (2009). Review of fluoride removal from drinking water. J. Environ. Manag. 91(1):67-77. doi:10.1016/j.jenvman.2009.08.015.

32.Nalawade, P.M., Bholay, A.D., and Mule, M. B. (2012). Assessment of groundwater and surface water quality indices for heavy metals nearby area of Parli thermal power plant. J. Environ. Res. Technol. 2 (1):47-51.

33.Namita Saxena et al., (2017). Evaluation of Water Quality Index for Drinking Purpose in and Around Tekanpur Area, M.P., India. Int. J. of Applied Sci. 12 (2):359-370. ISSN- 0973-6077.

34.Pandey, M. M. (2009) Country Report: India, 'Indian Agriculture- An Introduction'. Fourth Session of the Technical Committee of APCAEM, Chang Rai, Thailand.

35.Pandey, S. K. (2014). Coal fly ash: Some aspects of characterization and environmental impacts. J. Environ. Sci. Com. Sci. Engg. Technol. 3: 921-937.

36.Rabinove, C.J., Long Ford, R.H. and Brook Hart, J.W. (1958). Saline water resource of North Dakota U.S., US Geological Survey. Water Supply Paper. 1428: 72.

37.Rahi, A. (2011). Punjab: the physicochemistry of groundwater crisis. Int. Ref. Reseach J. 2009- 2011.

38.Ramesh, K., and Elango, L. (2012). Groundwater quality and its suitability for domestic and agricultural use in Tondiar river basin, Tamil Nadu, India. Environ. Monit. Assess. 184(6):3887-3899. DOI 10.1007/s10661-011-2231-3.

39.Rao, N.S, Devadas, D.J., and Rao, S.K.V. (2006). Interpretation of groundwater quality using principal component analysis from Anantapur district, Andhra Pradesh, India. Environ. Geosci. 13(4):239-259.

40.Rasouli, F., Pouya, A.K. and Cheraghi, S.A.M. (2012). Hydrogeochemistry and water quality assessment of the Kor-Sivand Basin, Fars province, Iran. Environ. Monit. Assess. 184(8):4861-4877.

41.Richards, L.A. (1954). (US Salinity Laboratory): Diagnosis and improvement of saline and alkaline soils, US Department of Agriculture hand book. pp. 60.

42.Sajitha V. and Vijayamma, S.A. (2016). Study of Physico Chemical Parameters and Pond Water Quality Assessment by using Water Quality Index at Athiyannoor Panchayath, Kerala, India. Emer Life Sci Res. 2(1):46-51, E-ISSN: 2395-6658.

43.Sarode, D.B., Jadhav, R.N., Khatik, V.A., Ingle, S.T., and Attarde, S.B. (2010). Extraction and Leaching of Heavy Metals from Thermal Power Plant Fly Ash and Its Adm ixtures. Polish J. of Environ. Stud. 19 (6): 1325-1330.

44.Shalu, Punia, S., and Malik, A. (2015). Hydrochemistry and water quality assessment of groundwater of Bhiwani district, Haryana, India. Envr. Res. 34:21-32.

45.Sulochana, N., Inbaraj, B.S. and Selvarani, K. (1998). Status of groundwater in a remote village near Tirunelveli in Tamil Nadu. Indian J. Environ. Prot. 18(10):739-744.

46.Tiwana, N.S., Jerath, N., Ladhar, S.S., Singh, G., Paul, R., Dua, D.K. and Parwana, H.K. (2007). State of Environment; Punjab-2007. Punjab State Council for Science \& Technology, 243.ISBN: 81-88362-19-0.

47. United States Environmental Protection Agency (USEPA) (2005). Ecological Soil Screening Levels for Lead, Interim Final. Office of Solid Waste and Emergency Response. OWSER Directive 9285:7-70. 1200 Pennsylvania Ave. N.W. Washington, D.C 20460. 
Verma, S. and Anju / J. Appl. \& Nat. Sci. 10 (3): 915 - 924 (2018)

48.USDA (United States Department of Agriculture) (1954). Diagnosis andlmprovement of Saline and Alkali Soils. Agriculture Handbook No. 60. US. Govt. Printing Office, Washington DC.

49.Verma, C., Madan, S., and Hussain, A. (2016). Heavy metal contamination of groundwater due to fly ash disposal of coal-fired thermal power plant, $\mathrm{Pa}$ - richha, Jhansi, India. Cogent Eng. 3: 1-8. https:// doi.org/10.1080/23311916.2016.1179243.

50.Water (Prevention and Control of Pollution) Act (1974).hspcb.gov.in/Water_Act_1974.pdf

51.World Health Organization (WHO) (2017). Guidelines for drinking water, fourth edition incorporated to the first addendum. 